\title{
Women Don't Ask? Women Don't Say No? Bargaining and Service in the Political Science Profession
}

Sara McLaughlin Mitchell, University of Iowa

Vicki L. Hesli, University of Iowa

ABSTRACT This article examines the dual problems of "women don't ask" and "women don't say no" in the academic profession. First, we consider whether female faculty bargain more or less frequently than male faculty about such resources as salary, research support, clerical support, moving expenses, and spousal accommodation. Analyzing a 2009 APSA survey, we find that women are more likely to ask for resources than men when considering most categories of bargaining issues. This finding goes against conventional wisdom in the literature on gender and bargaining that suggests that women are less likely to bargain than men. Second, we seek to understand if women are reluctant to say no when asked to provide service at the department, college, university, or disciplinary levels. We find that women are asked to provide more service and that they agree to serve more frequently than men. We also find that the service women provide is more typically "token" service, as women are less likely to be asked by their colleagues to serve as department chair, to chair committees, or to lead academic programs. The implications of these results for the leaky pipeline in the academic profession are discussed.

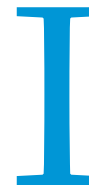

$\mathrm{n}$ this article, we examine the dual problems of "women don't ask" and "women don't say no" in academia. The first issue, "women don't ask," deals with the potential differences between men and women in bargaining situations. Surveying the literature on negotiations and the gender divide, Babcock and Laschever (2003) report that women bargain less frequently than men in a wide variety of situations from salary negotiations to the timing of promotion reviews in academic careers. Failure to negotiate an initial salary offer can have lifelong repercussions that may cost a job candidate several hundred thousand dollars over the course of a career. This gap is also difficult to close; even if women receive higher percentage annual raises, women's salaries lag behind men's salaries if they have a lower starting salary (Gerhart 1990). The lack of bargaining for promotion may contribute to the leaky pipeline in the academic profession, whereby women represent a smaller percentage of scholars within higher academic ranks, especially at the full professor level (Allen 1998; Bellas and Toutkoushian 1999; Hesli and Lee 2011).

Sara McLaughlin Mitchell is a professor in the department of political science at the University of Iowa. She can be reached at sara-mitchell@uiowa.edu.

Vicki L. Hesli is a professor in the department of political science at the University of Iowa. She can be reached at vicki-hesli@uiowa.edu.
The second issue, "women don't say no," relates to whether female academics engage in professional service more often than their male peers. While some studies find few differences in the number of hours male and female faculty devote to service (Bellas and Toutkoushian 1999; Russell, Fairweather, and Hendrickson 1991; Singell, Lillydahl, and Singell 1996), others find that female faculty and faculty of color are more likely than their comparative counterparts to engage in service to their institution and their profession (Turk 1981; Turner 2002; Turner and Myers 2002). Women may also be asked to provide less-prestigious service (Twale and Shannon 1996). ${ }^{1}$ Misra et al. (2011) find that women are more than twice as likely as men to be asked to serve as the director of undergraduate students, but they are less likely to be tapped for prestigious service such as department chair or program director. The provision of more frequent and less-prestigious service could contribute to female scholars spending less time on research relative to male scholars, which could explain the overall lower number of total career articles published by women relative to men (Allen 1998; Hesli and Lee 2011).

We examine these important issues for the political science profession by analyzing a 2009 survey conducted by the APSA (Hesli and Lee 2011). This survey of 1,399 faculty members of political science departments throughout the United States asks a 
variety of questions about resources and service. To address the question of "women don't ask," we consider whether female professors bargain more or less frequently than male professors about such issues as salary, research support, clerical support, moving expenses, and spousal accommodation. Our analyses show that women are more likely than men to ask for and receive most of these resources. This goes against conventional wisdom in the literature on gender and bargaining that suggests that women are less likely to bargain for what they need. ${ }^{2}$

The APSA survey also allows us to analyze the issue of "women don't say no" by tapping a variety of different types of professional service at the department, college, university, and disciplinary levels. The survey also usefully distinguishes between volunteering for service, being asked to serve, and agreeing to serve for each category of service. We find that female professors are asked to provide more service than their male colleagues and that they more frequently agree to serve. We also find that the type of service women provide is more typically "token" service, as women are less likely to be asked by their colleagues to serve as department chair, committee chair, or the director of an academic program.

To address these questions, we begin with a discussion of the leaky pipeline in the academic profession and discuss how bargaining and service relate to the declining proportion of women faculty at higher academic ranks. Next, we summarize previous literature on the topics of gender, negotiation, and service. Then we provide a brief description of the survey instrument and methodology used. Finally, we present the empirical results from the APSA survey and discuss the implications of our findings for women's status in political science and in academia more generally.

\section{THE LEAKY PIPELINE}

Many studies have evaluated the status of women in the academic profession over the past three decades. Evidence for a significant gender gap has been demonstrated with respect to salaries (Bell 2001; Blackaby, Booth, and Frank 2005; Henehan and Sarkees 2009), publication rates and journal/book press placement (Breuning, Bredehoft, and Walton 2005; Breuning and Sanders 2007; Hesli and Lee 2011; Jaschik 2005; Mathews and Andersen 2001), employment at research versus teaching institutions (Sarkees and McGlen 1999), satisfaction with graduate school training (Hesli, Fink, and Duffy 2003), and attrition rates at all academic levels (Sarkees and McGlen 1999). Although recent studies show some decline in the academic gender gap (Henehan and Sarkees 2009; Hesli et al. 2006), female scholars are still underrepresented at high-rank levels relative to the number of women receiving undergraduate degrees.

The 2009 faculty survey conducted by the APSA (Hesli and Lee 2011) shows that the empirical pattern of a leaky pipeline exists in the political science profession. Table 1 shows that women faculty constitute smaller percentages at higher academic ranks. Among female respondents, $3 \%$ are lecturers, $42 \%$ are assistant professors, $26 \%$ are associate professors, and $29 \%$ are full professors. This compares to $2 \%$ lecturers, $26 \%$ assistant professors, $28 \%$ associate professors, and $44 \%$ percent full professors among male respondents. These differences are statistically significant at the $99 \%$ confidence level. ${ }^{3}$ In political science the leaky pipeline accords with analyses of data in other academic disciplines, where studies control for numerous factors that explain promotion to higher academic ranks. Toutkoushian (1999) finds that female profes-

$\begin{aligned} & \text { Table } 1 \\
& \text { Leaky Pipeline-APSA }\end{aligned}$
\begin{tabular}{lccc} 
2009 Survey Data & WOMEN & MEN & TOTAL \\
\begin{tabular}{lccc} 
RANK & $11(3.2 \%)$ & $20(2.1 \%)$ & $31(2.4 \%)$ \\
\hline Lecturer & $144(42.1 \%)$ & $252(26.2 \%)$ & $396(30.3 \%)$ \\
\hline Assistant Professor & $88(25.7 \%)$ & $269(27.9 \%)$ & $357(27.4 \%)$ \\
\hline Associate Professor & $99(29.0 \%)$ & $422(43.8 \%)$ & $521(39.9 \%)$ \\
\hline Full Professor & $342(26.2 \%)$ & $963(73.8 \%)$ & 1,305 \\
\hline Total & & & \\
\hline$\chi^{2}(3)=36.9 * *$ & &
\end{tabular} \\
\hline **Significant at 95\% level.
\end{tabular}

sors are significantly less likely to achieve the ranks of tenured professor or full professor than male professors, controlling for the faculty member's race, years of experience, and research productivity such as career total of books, journal articles, and book chapters. Perna (2001) reaches similar conclusions in her analysis of data from the 1993 National Study of Postsecondary Faculty. She finds that women at four-year institutions are significantly less likely than men to be promoted to the rank of full professor when controlling for differences in human capital, research productivity, and structural characteristics.

The issues of "women don't ask" and "women don't say no" are crucial for analyzing the leaky pipeline in academia for two reasons. First, the lack of women at senior ranks increases the service burden of women at the upper ranks. Administrators and professional associations seek to create committees that are representative of different constituent groups, which typically increases the service burden for more senior female faculty and other minority groups, such as African Americans or Latinos. If women devote more time to service activities relative to research, this could slow their research productivity and contribute to the gender gap in publications. Lower productivity, in turn, could slow the pace of women's salary trajectories. Second, if women are more reluctant to bargain their initial faculty salaries, this could enhance gender differences in salary at all ranks. The most recent 2010-2011 salary data from the American Association of University Professors (AAUP) show that female faculty members earn $81 \%$ of male faculty's salaries when considering all types of academic institutions. ${ }^{4} \mathrm{At} \mathrm{PhD}$-granting institutions, the gap is even wider, as women's salaries are only $78 \%$ of men's salaries. Many institutions grant significant salary increases at promotion steps, thus the two problems are related, because the lack of progress for some women up through the academic ranks suppresses their salaries relative to male peers. Yet we have little evidence about whether these problems of less bargaining and excessive service are pervasive in political science. Empirical analyses of the 2009 APSA survey provide valuable insights into these important issues.

\section{WOMEN DON'T ASK?}

In their book, Women Don't Ask: Negotiation and the Gender Divide, Babcock and Laschever $(2003,1-3)$ argue that women negotiate much less frequently than men, with men renegotiating offers three to four times more often than women (Babcock et al. 2006). The authors' research confirmed this pattern when examining starting salaries of graduates with masters' degrees from Carnegie 
Mellon University . Male graduates renegotiated their initial salary offers eight times as often as women, which translated into a $\$ 4,053$ starting-salary differential. The findings were also demonstrated in experimental settings, where men asked for more money after playing the game Boggle nine times as often as female experimental subjects (Bowles, Babcock, and Lai 2006). In several experiments the authors confirmed that women negotiate less frequently than men and that women are often made worse off when they initiate negotiations-both male and female participants evaluate women less favorably when women are observed initiating negotiations. Rudman's (1998) experiments showed that these backlash effects might be stronger when women negotiate with other women as they are perceived to violate their gender's cooperative negotiation norms.

Several negative consequences emerge when women negotiate less frequently than men, especially in workplace situations. First, failure to negotiate contributes to the salary gap between advancement" (Greig 2008, 502). Similar patterns have been observed in academic settings. Controlling for productivity and experience, women are less likely to achieve higher academic ranks than men (Toutkoushian 1999). Studies also show that female faculty members are less likely to put themselves forward for administrative positions (Chesterman, Ross-Smith, and Peters 2005), which could contribute to the male-female academic salary gap. As we show in the next section, this could be exacerbated by male colleagues failing to ask their female colleagues to take on important administrative positions.

\section{Women Don't Say No?}

In this section, we review research on allocation of faculty time, focusing on gender differences in the amount and type of service provided to the university and the academic profession. Knowledge of how academics allocate their work time to different aspects of their job helps explain the leaky pipeline in political science

\section{If women spend more time on teaching and service relative to research, this could contribute to the publication gap between male and female faculty. With fewer women at higher academic ranks, fewer women are available to do the service required at associate professor and full professor levels. Thus, senior women could be doing more service than senior men.}

men and women in professional settings. Babcock and Laschever $(2003,6465)$ provide a useful example of a female plant biologist at a large state university who realized she was underpaid relative to her male coauthor when they jointly applied for a research grant. When she spoke to her colleague about the salary difference, he told her that he negotiated his salary each year, with a goal of achieving a $3 \%$ or higher increase. The female scholar had not negotiated her salary until she realized, given her publications and grants record, that she was underpaid. The backlash against women may also hurt them in negotiations. When women try to negotiate their salary, they receive lower wages than their male counterparts (Gerhart and Rynes 1991). Women are also less likely to receive outside job offers, and they are less likely to receive matching counteroffers from their current employers when they are successful in obtaining outsider offers (Blackaby, Booth, and Frank 2005).

Second, the leaky pipeline described earlier could be a function of women not pushing for promotion to higher academic ranks. Greig (2008) analyzed negotiation and promotion patterns in a large US investment bank, surveying more than 300 employees. She had access to detailed information about the number and dates of promotions for each employee. At the end of the survey, she gave participants an option to receive a Starbucks gift card and to specify the amount of the gift card. Greig found that women were significantly less likely to ask for a gift card in comparison to men; close to $25 \%$ of all women did not ask for a card, compared to $10 \%$ of men. She also found that this lower frequency of negotiation was consequential for employees' careers at the bank as well; women who negotiated less for the gift cards also experienced longer time periods since their last promotion. "People who made a Starbucks card request were promoted more than 17 months sooner at each promotion... These findings provide strong evidence that propensity to negotiate is associated with quicker and other academic professions. If women spend more time on teaching and service relative to research, this could contribute to the publication gap between male and female faculty. With fewer women at higher academic ranks, fewer women are available to do the service required at associate professor and full professor levels. Thus, senior women could be doing more service than senior men.

Several empirical studies have analyzed data from the National Survey of Postsecondary Faculty (NSOPF), which has collected data on 7,00o to more than 18 ,ooo faculty members across all disciplines. The survey was conducted in several waves: 1987-1988, 1992-1993, 1998-1999, and 2003-2004. Earlier studies examining these survey data find that faculty work 50 to 55 hours per week on average (Jacobs 2004, 7; Link, Swann, and Bozeman 2008, 365). The number of hours faculty spend on research, teaching, and service has increased over time (Milem, Berger, and Dey 200o). In a 2008-09 survey, Misra et al. (2011) find the average number of faculty weekly hours worked is 64 hours. Several factors explain variance in the amount of hours worked by full-time faculty including marital status, rank, age, institution type, administrative positions, and field (Jacobs 2004).

Gender patterns have been analyzed in studies of faculty time allocation. Some NSOPF studies find few differences in the total hours male and female faculty devote to service (Bellas and Toutkoushian 1999; Russell, Fairweather, and Hendrickson 1991; Singell, Lillydahl, and Singell 1996), while other scholars find that female faculty and faculty of color are more likely to engage in service to their institution and their profession (Turk 1981; Turner 2002; Turner and Myers 2002). A 2008-2009 study of 350 faculty members at the University of Massachusetts by Misra et al. (2011) found that women are often taxed to do more service in academia, especially as they become more senior. In an analysis of female faculty in science and engineering disciplines, Link, Swann, and 
Bozeman $(2008,366)$ reach a similar conclusion: "women work slightly more hours than men, and they spend more time on teaching, grant writing, and service but less time on research."

Female faculty members also tend to be more involved in university governance than their male peers. Although overall differences in committee participation is small, "Female faculty at doctoral universities report serving on ... about one half more total committees than males ... females at doctoral institutions spend $15 \%$ more hours on committee work than males" (Porter 2007, 532-34). Similar patterns were uncovered in studies examining participation by faculty on university-wide committees. "An analysis of academic governance in the California university system found that female faculty were more likely than male faculty to have positions on university-wide committees" (Porter 2007, 527). This confirmed an earlier study by Turk $(1981,221)$ that analyzed faculty participation on university committees for 19 California schools; she found "a consistent pattern of marked over participation by women."

Analyses of faculty time allocation also suggest that female faculty spend more time on teaching than male faculty (Singell, Lillydahl, and Singell 1996; Winslow 2010)..$^{5}$ Allen's (1998) analysis of the 1993 NSOPF survey found that female faculty devote a higher percentage of their overall time to teaching: "Women faculty ... devoted large proportions of their professional time to instruction ... Women gave $47 \%$ of their time to teaching, $18 \%$ to research, and $29 \%$ to administration and service. Men devoted only $41 \%$ of their time to teaching, but gave $27 \%$ of their time to research" (Allen 1998, 33). Misra et al. (2011) confirm the gap between male and female faculty in their time devoted to research, with men spending seven and a half extra hours on research per week, which could explain why women have significantly fewer published articles. Misra et al. (2011) found stark differences in time allocation at the associate professor level: "male associate professors spent $37 \%$ of their time on research, while women associate professors spent $25 \%$ of their time on research. While women associate professors spent $27 \%$ of their time on service, men spent $20 \%$ of their time on service ... Men and women associate professors spent about the same amount of time on service to the profession (5.4 hours a week), but women spent much more time on service to the university (11.6 hours versus 7 hours)" (Misra et al. 2011, 2).

Explanations for differences in service provision include the argument that women and minority faculty are often selected for committee work by administrators to ensure diversity and fair representation (Park 1996). Women are more likely than men to view service as vital to their university and important for mentoring students. Women also report stronger feelings of guilt for burdening other faculty and graduate students with service they fail to provide (Misra et al. 2011). A perceived need to change policies and practices in the university governing system can also result in women and minority faculty members engaging in a higher level of service (Park 1996).

In addition to differences in the amount of service female faculty provide, studies also reveal differences in the types of service that men and women provide. Some studies conclude that women are more likely to provide "token" service, as men are more likely than women to be tapped for prestigious service positions such as department chair, program chair, journal editor, or dean. In educational administration, Twale and Shannon $(1996,119)$ found that male faculty had more years of administrative experience, especially at the department level. Misra et al. $(2011,1)$ also found that men were much more likely to have served as department chair: "among full professors $-35 \%$ of men have chaired, while only $14 \%$ of women have done so."

Misra et al. (2011) found that women were taking lessprestigious, time-consuming service jobs, therefore being twice as likely to serve as director of undergraduate studies than their male faculty peers. Monroe et al. (2008) describe the pattern of women holding less-prestigious administrative positions as gender devaluation, whereby administrative positions lose their aura or authority when held by women. Women are also reluctant to apply for administrative jobs unless asked to do so (Chesterman, Ross-Smith, and Peters 2005), which contributes to a higher percentage of their overall service duties being less prestigious. Studies of committee work have confirmed this pattern, showing distinctions across types of committees: "Qualitatively, the type of committees on which women served differed. Women reported serving on nominating, membership, awards, graduate student, and steering committees, while men reported sitting on leadership, policy, and assessment committees" (Twale and Shannon, 1996, 120-21). In short, women might be agreeing to do more service for their universities and their professions, but these activities may not pay off in the same way they do for men given the token nature of many of these roles. The APSA survey data are extremely useful for determining if the patterns of "women don't ask" and "women don't say no" are pervasive in the political science profession.

\section{RESEARCH DESIGN}

To see how these issues influence women in the academe, we analyze a 2009 APSA survey of 1,399 faculty members of US political science departments. We describe the survey methodology in detail in appendix B (see also Hesli and Lee 2011). Political science data provide a good sample for generalizing to the broader sample of university faculty given that the percentage of women receiving $\mathrm{PhDs}$ in political science is fairly close to the average for all academic professions. ${ }^{6}$ The questions in the survey are ideal for analyzing gender patterns of bargaining and service. To capture potential gender differences in bargaining, we use a question, Bargaining for Resources, that asks whether respondents have received various resources as a result of their own negotiations (asked/ bargained for by me), as part of an external award, or as part of an offer by the university. This includes any resources received since the initial contract for the respondent's current position. The resources listed include course release time, research assistants, discretionary funds, travel funds, summer salary, special timing of tenure track, moving expenses, housing subsidies, child care, partner/spouse position, and clerical/administrative support. For each respondent, we generated a count variable for all resources received within each category of how the resources were obtained: asked/bargained for by me (1.46), part of an external award (0.53), or offered by university (2.27). ${ }^{7}$

To examine gender differences in academic service, we look at different types of service at the department, college, university, and disciplinary levels. Our first indicator, Undergraduate Projects Supervised, counts the total number of honors theses, independent studies, and senior projects that a respondent supervises each semester (mean $=3.73$ ). The second measure, Total Advisees, captures the number of students that a respondent advises in an official capacity at the undergraduate, $\mathrm{MA}$, and $\mathrm{PhD}$ levels, as well as 
the number of postdocs and junior faculty that the respondent supervises $($ mean $=24)$. We generate count variables to capture Service to Department, College, and University by summing across department-, college-, and university-level committee assignments. We calculate counts of committee assignments on the basis of how respondents were recruited: volunteered (0.52), asked to serve (1.23), served (2.69), and chaired (1.03). We also examine a question of whether respondents are asked by their colleagues to serve as department chair $(41 \%$ yes, $59 \%$ no) or to direct a department program or section ( $41 \%$ yes, $59 \%$ no). Our final measures for service denote Service to Discipline including (means in parentheses) number of books reviewed (2.52), number of articles reviewed (8.74), number of editorial boards (0.71), and number of professional committees (1.05). We also generate a count variable for Total Service that sums across all types of disciplinary service (mean $=15.46)$.

To test our hypotheses relating gender to bargaining and service, we also estimate multivariate models that control for a variety of factors. Because the dependent variables are event counts, we use negative binomial models to allow for the possibility that events are not independent from each other. The first control variable, Rank, consists of four possible appointment levels ( $1=$ instructor/post-doc/ lecturer/fellow, $2=$ assistant professor, 3 = associate professor, $4=$ professor; see table 1 for distribution). ${ }^{8}$ Female is coded one for women $(25 \%)$, zero for men (75\%). Minorityis coded one if the respondents identify themselves as a member of an ethnic or racial minority group ( $11 \%$ yes, $89 \%$ no). Children is a dummy variable that equals one if the respondent or their spouse or partner has any children ( $53 \%$ yes, $47 \%$ no). We also control for structural factors that could vary across institutions by distinguishing between $P h D$ granting programs (32\%), MA granting programs (19\%), and other types of universities and colleges (these are primarily bachelor degree-

Table 2

Table 3
Bargaining for Resources ${ }^{a}$

\begin{tabular}{|c|c|c|c|}
\hline INDEPENDENT VARIABLES & $\begin{array}{c}\text { TOTAL RESOURCES } \\
\text { ASKED FOR/BARGAINED }\end{array}$ & $\begin{array}{l}\text { TOTAL RESOURCES, } \\
\text { EXTERNAL AWARD }\end{array}$ & $\begin{array}{l}\text { TOTAL RESOURCES, } \\
\text { PART OF UNIVERSITY OFFER }\end{array}$ \\
\hline \multirow[t]{2}{*}{ Rank } & 0.012 & $0.501^{* *}$ & -0.043 \\
\hline & $(0.04)$ & $(0.08)$ & $(0.03)$ \\
\hline \multirow[t]{2}{*}{ Female } & $0.245^{* *}$ & $0.284^{*}$ & $0.164^{* *}$ \\
\hline & $(0.08)$ & $(0.15)$ & $(0.06)$ \\
\hline \multirow[t]{2}{*}{ Minority } & $0.298^{* *}$ & -0.179 & 0.019 \\
\hline & $(0.11)$ & $(0.21)$ & $(0.08)$ \\
\hline \multirow[t]{2}{*}{ Children } & $0.219 * *$ & $0.587^{* *}$ & $0.366^{* *}$ \\
\hline & $(0.07)$ & $(0.14)$ & $(0.06)$ \\
\hline \multirow[t]{2}{*}{ PhD program } & $0.304^{* *}$ & $1.087^{* *}$ & $0.210 * *$ \\
\hline & $(0.08)$ & $(0.15)$ & $(0.06)$ \\
\hline \multirow[t]{2}{*}{ MA program } & 0.049 & $0.588^{* *}$ & 0.115 \\
\hline & $(0.10)$ & $(0.18)$ & $(0.07)$ \\
\hline \multirow[t]{2}{*}{ Tenured female faculty in department } & 0.167 & -0.183 & 0.004 \\
\hline & $(0.12)$ & $(0.25)$ & $(0.09)$ \\
\hline \multirow[t]{2}{*}{ Outside offer } & $0.399 * *$ & $0.641^{* *}$ & $0.263^{* *}$ \\
\hline & $(0.08)$ & $(0.14)$ & $(0.06)$ \\
\hline \multirow[t]{2}{*}{ Constant } & -0.109 & $-3.491^{* *}$ & $0.563^{* *}$ \\
\hline & $(0.15)$ & $(0.31)$ & $(0.11)$ \\
\hline Observations & 1,305 & 1,305 & 1,305 \\
\hline Test of $\alpha=0$ & $\chi^{2}=461.6^{* *}$ & $\chi^{2}=442.8^{* *}$ & $\chi^{2}=317.7^{* *}$ \\
\hline
\end{tabular}

aStandard errors in parentheses; * significant at 90\% level; ** significant at 95\% level.

What Do Women Bargain For?

\begin{tabular}{|c|c|c|c|c|c|c|}
\hline \multirow[b]{2}{*}{ CATEGORY } & \multicolumn{2}{|c|}{ ASKED FOR } & \multicolumn{2}{|c|}{ PART OF EXTERNAL AWARD } & \multicolumn{2}{|c|}{ OFFERED BY UNIVERSITY } \\
\hline & Women $^{\mathrm{a}}$ & Men & Women & Men & Women & Men \\
\hline Course Release Time & $32.7 \% *$ & $23.3 \%$ & $13.5 \%$ & $10.1 \%$ & $40.1 \% *$ & $29.9 \%$ \\
\hline Research Assistant & $23.5 \% *$ & $14.7 \%$ & $13.5 \%$ & $10.4 \%$ & $28.4 \%$ & $23.6 \%$ \\
\hline Discretionary Funds & $21.5 \% *$ & $16.1 \%$ & $3.2 \%$ & $6.6 \% *$ & $23.5 \%$ & $22.1 \%$ \\
\hline Travel Funds & $31.2 \% *$ & $23.9 \%$ & $8.6 \%$ & $10.5 \%$ & $64.8 \% *$ & $49.3 \%$ \\
\hline Summer Salary & $20.1 \%$ & $18.1 \%$ & $14.3 \% *$ & $8.9 \%$ & $26.4 \%$ & $27.9 \%$ \\
\hline Special Timing of Tenure Track & $11.2 \%$ & $9.4 \%$ & $0 \%$ & $0.1 \%$ & $9.2 \% *$ & $6.1 \%$ \\
\hline Moving Expenses & $20.6 \% *$ & $15.3 \%$ & $0.6 \%$ & $0.7 \%$ & $37.5 \% *$ & $28.6 \%$ \\
\hline Housing Subsidy & $1.2 \%$ & $1.5 \%$ & $0 \%$ & $0.5 \%$ & $4.3 \%$ & $4.1 \%$ \\
\hline Child Care & $0.9 \%$ & $0.6 \%$ & $0 \%$ & $0 \%$ & $4.3 \% *$ & $1.5 \%$ \\
\hline Partner/Spouse Position & $8.3 \% *$ & $3.6 \%$ & $0 \%$ & $0 \%$ & $2.3 \%$ & $2.0 \%$ \\
\hline Clerical/Administrative Support & $6.0 \%$ & $7.3 \%$ & $2.3 \%$ & $4.7 \% *$ & $24.9 \% *$ & $18.4 \%$ \\
\hline
\end{tabular}

aThe percentages represent the percentage of men and women who asked for or received the designated item from their university. An asterisk indicates the chi-square test for independence produces a value greater than the $95 \%$ critical value.

granting institutions-the omitted baseline, $49 \%$ ). To capture structural or climate differences at the department level, we include a dummy variable for Tenured Female Faculty in Department that equals one if the respondent's department has one or more female tenured faculty ( $9 \%$ yes, $91 \%$ no). Our final variable, Outside Offer, helps to consider a respondent's potential for outside options $(27 \%$ 
yes, $73 \%$ no). It is important to include this variable given that resources, especially those that faculty may ask for or receive through an external award, may be received through the process of receiving an offer from another university.

\section{EMPIRICAL RESULTS}

We begin with an analysis of the question "women don't ask" by looking at differences between male and female faculty in resources that they bargain for and report receiving. As noted earlier, we separate the bargaining count variables by considering how the resources were obtained: asked for/bargained for by me, part of external award, or part of university offer. We see in table 2 that female respondents are significantly more likely to bargain for and report receiving a higher number of resources in each of these categories. Respondents at higher rank are more likely to obtain resources through external awards. Respondents with children and those who work at a $\mathrm{PhD}$-granting institution report a significantly higher level of bargaining across all measures. ${ }^{9}$ Obtaining an outside offer also leads to bargaining for and receiving more resources.

We also estimate the bargaining models in table 2 for split samples of assistant professors only and tenured professors (associate/full) to determine how rank might influence the relationship between gender and bargaining. ${ }^{10}$ For the "part of external award" category, Female is positive and significant only for the assistant professor subsample and insignificant for the associate/full professor subsample. Junior women may wait for good opportunities to bargain, such as when they receive an outside offer. However, the model for the "offered by university" category shows that Female is positive and significant in both subsamples (assistant or associate/full). For the "asked for/bargained for by me" resources category, Female is positive and significant only for the associate/full professor group. This reflects a more active decision by tenured female faculty to bargain for (and report receiving) resources, something they may learn as their advance through their career. This could also occur if senior women have fewer external options for career advancement due to spousal or family issues.

In table 3, we look at gender differences across 11 different types of resources that may benefit faculty members in their careers. Using a simple bivariate analysis, we see that in the "asked for" category, women are more likely than men to pursue course release time, research assistants, discretionary or travel funds, moving expenses, or a position for their partner or spouse. In contrast, women are not significantly more likely to request summer salary, special timing, housing subsidy, child care or clerical assistance. On one hand, it is surprising that women are not more likely to bargain for issues that may more directly affect them than men, such as child care or the special timing of the tenure track. Of course, we do not have information about the policies that exist at the respondents' institutions on these issues, so the lack of bargaining on an issue like tenure clock timing could reflect a policy already in place that

Table 5

Table 4

\section{Gender and Academic Service}

\begin{tabular}{|c|c|c|}
\hline CATEGORY & WOMEN ${ }^{\mathrm{a}}$ & MEN \\
\hline \multicolumn{3}{|l|}{ Undergraduate Projects Supervised } \\
\hline Number of honors thesis & 0.79 & 0.67 \\
\hline Number of independent studies & 1.23 & 1.32 \\
\hline Number of senior projects & 1.20 & 1.00 \\
\hline \multicolumn{3}{|l|}{ Advisees } \\
\hline Undergraduates & $15.63^{* *}$ & 13.18 \\
\hline MA students & 3.18 & 2.28 \\
\hline PhD students & 0.92 & 0.99 \\
\hline Postdocs & 0.01 & $0.03^{*}$ \\
\hline \multicolumn{3}{|l|}{ Service $\left(\right.$ Internal) ${ }^{\mathrm{b}}$} \\
\hline Department level committees & $1.64 * *$ & 1.37 \\
\hline School/college level committees & $0.80^{* *}$ & 0.63 \\
\hline University level committees & 0.61 & 0.56 \\
\hline \multicolumn{3}{|l|}{ Service (External) } \\
\hline Book reviews & 2.58 & $3.47^{* *}$ \\
\hline Article reviews & 9.51 & $11.85^{* *}$ \\
\hline Served on editorial boards & 1.00 & 0.99 \\
\hline Served on professional committees & $1.75^{* *}$ & 1.35 \\
\hline \multicolumn{3}{|c|}{$\begin{array}{l}\text { aThe values represent the means for each group. An asterisk indicates the } t \text {-test for } \\
\text { the difference of means between groups produces a calculated value greater than } \\
\text { the } 90 \text { percent critical } t \text {-score; two asterisks indicate significance for the difference of } \\
\text { means test at the } 95 \text { percent level. }\end{array}$} \\
\hline & & \\
\hline
\end{tabular}

Total Number of Undergraduate Projects Supervised ${ }^{\text {a }}$

\begin{tabular}{lccc} 
INDEPENDENT VARIABLES & $\begin{array}{c}\text { ALL } \\
\text { RESPONDENTS }\end{array}$ & MEN & WOMEN \\
\hline Rank & $0.236^{* *}$ & $0.268^{* *}$ & $0.158^{* *}$ \\
& $(0.047)$ & $(0.058)$ & $(0.078)$ \\
\hline Female & 0.059 & - & - \\
\hline Minority & $(0.081)$ & & \\
\hline Children & 0.108 & $0.238^{*}$ & -0.154 \\
& $(0.108)$ & $(0.136)$ & $(0.176)$ \\
\hline PhD program & $0.149^{*}$ & 0.089 & $0.244^{*}$ \\
& $(0.082)$ & $(0.103)$ & $(0.134)$ \\
\hline MA program & $-0.197^{* *}$ & -0.052 & $-0.466^{* *}$ \\
& $(0.085)$ & $(0.106)$ & $(0.141)$ \\
\hline Tenured female faculty & -0.075 & -0.050 & -0.103 \\
in department & $(0.101)$ & $(0.123)$ & $(0.172)$ \\
\hline Outside offer & $0.260^{* *}$ & $0.440^{* *}$ & -0.350 \\
& $(0.117)$ & $(0.137)$ & $(0.227)$ \\
\hline Constant & 0.132 & 0.069 & 0.225 \\
& $(0.084)$ & $(0.102)$ & $(0.150)$ \\
\hline Observations & $0.436^{* *}$ & 0.300 & $0.816^{* *}$ \\
\hline Test of $\alpha=0$ & $(0.162)$ & $(0.196)$ & $(0.244)$ \\
\hline aStandard errors in parentheses; ${ }^{*}$ significant at $90 \%$ level; ** significant at $95 \%$ level. & 313 \\
\hline & 981 & 668 & $\chi^{2}=551.04^{* *}$ \\
\hline
\end{tabular}


provides this support to probationary faculty. ${ }^{11}$ On the other hand, we see women bargaining more for many resources that could be treated as "gender neutral" issues, such as travel funds, discretionary funds, or research assistants. Overall our evidence suggests that women bargain more frequently than men, suggesting that the behavior of female faculty may be different compared to the women who have been the focus of earlier studies relating gender and bargaining.

Note that the survey question asks if respondents have received any of the resources through the three primary mechanisms (asked for/ bargained by me, part of an external award, or offered by university). Perhaps, some nonresponse cases reflect situations where respondents have asked for these resources but did not receive them. If women are less successful than men in negotiations, the coded data could come from a biased subset of women (and men) who have been particularly successful in asking for and receiving various resources. Although the APSA survey does not include a question about the respondent's salary, it does include a question about whether a respondent felt any salary discrimination on the basis of gender. A small percentage of total respondents answer affirmatively to this question (7.93\%), and female respondents are significantly more likely to report gender-based salary discrimination than male respondents $(79.28 \%$ of the respondents in the 7.93\% group are female). With respect to salary, this preliminary evidence indicates that women may feel like they are not adequately compensated and that such differences partly stem from gender-based discrimination. Thus, engaging in bargaining activities and being satisfied with the outcomes of bargaining may represent different dynamic processes. ${ }^{12}$

Now we turn to an analysis of the second question, whether "women don't say no" when it comes to providing service to their department, university, and the profession. In table 4, we present difference of means tests for a variety of the service variables used in the multivariate models. In table 5 , we estimate multivariate event count models for the total number of undergraduate projects supervised for the full sample and separate subsamples for male and female respondents. In the analyses for the full sample we see that the coefficient for Female is positive but not statistically significant. This lack of significance can also be seen in the difference of means test in table 4 for each component measure (honors theses, independent studies, and senior projects). On one hand, the subsample results for gender in table 5 suggest that at higher ranks, male respondents supervise more undergraduate projects than female respondents ( 0.268 coefficient for men versus 0.158 coefficient for women), while women employed in departments offering a $\mathrm{PhD}$ supervise fewer undergraduate projects than do men.

On the other hand, women have a significantly higher number of total advisees, as we can see in table 6. The coefficient for Female is positive and statistically different from zero $(p<.05)$, thus women are working with a larger number of advisees than men. The subsample results show that women supervise more advisees as they progress through higher ranks as well. The coefficient for Rank is more than three times larger (0.386) for women than men (o.117). The aggregate findings for table 6 are driven by female faculty advising more undergraduate students than male faculty; men show a higher average level of supervision only for postdocs, arguably a more prestigious advising role. Among the control variables in table 6, faculty who work at $\mathrm{PhD}$-granting universities tend to have fewer total advisees than faculty at MA- or BA-granting institutions. Having children reduces the total number of advisees but increases the number of undergraduate projects supervised, especially for female faculty. ${ }^{13}$

In table 7, we examine respondents' service to the department, college, or university summing across various types of committee service relative to the manner of recruitment (volunteered, asked to serve, served, chaired, etc.). We also look at whether respondents have been asked by their colleagues to serve as department chair or to head a program in the department. On one hand, with respect to volunteering for service, we see no statistically significant difference between male and female respondents. On the other hand, the coefficient for Female is positive and statistically different from zero $(p<.05)$ for being asked to serve and for agreeing to serve. This confirms previous findings in the literature that shows that female faculty are doing more service than male faculty. The difference of means tests in table 4 also show that gender differences are driven by service to the department and college, but there is no significant difference at the university level. We also see in table 7 that rank has a positive and significant effect on being asked to provide service and doing more service work. 
Table 7

Service to Department, College, and University ${ }^{\text {a }}$

\begin{tabular}{l|cc|cc|cc}
\multirow{2}{*}{$\begin{array}{l}\text { INDEPENDENT } \\
\text { VARIABLES }\end{array}$} & \multicolumn{2}{|c|}{ RECRUITMENT $^{\mathbf{b}}$} & \multicolumn{2}{c|}{ STATUS } & \multicolumn{2}{c}{ ASKED TO ADMINISTRATEc } \\
\cline { 2 - 7 } & Volunteered & $\begin{array}{c}\text { Asked } \\
\text { to Serve }\end{array}$ & Served & Chaired & $\begin{array}{c}\text { Department } \\
\text { Chair }\end{array}$ & $\begin{array}{c}\text { Dept. Program or } \\
\text { Section Director }\end{array}$ \\
\hline Rank & $0.146^{* *}$ & $0.122^{* *}$ & $0.155^{* *}$ & $0.207^{* *}$ & $1.769^{* *}$ & $0.904^{* *}$ \\
& $(0.05)$ & $(0.04)$ & $(0.02)$ & $(0.04)$ & $(0.12)$ & $(0.09)$ \\
\hline Female & 0.010 & $0.110^{*}$ & $0.101^{* *}$ & $-0.137^{* *}$ & $-0.491^{* *}$ & $-0.346^{* *}$ \\
& $(0.089)$ & $(0.06)$ & $(0.04)$ & $(0.065)$ & $(0.18)$ & $(0.16)$ \\
\hline Minority & -0.056 & $-0.138^{*}$ & -0.070 & 0.010 & -0.086 & $0.393^{*}$ \\
\hline Children & $(0.12)$ & $(0.08)$ & $(0.06)$ & $(0.08)$ & $(0.23)$ & $(0.20)$ \\
\hline PhD program & -0.013 & 0.038 & 0.058 & 0.045 & 0.280 & $0.338^{* *}$ \\
\hline MA program & $(0.09)$ & $(0.06)$ & $(0.04)$ & $(0.07)$ & $(0.18)$ & $(0.16)$ \\
\hline Tenured female faculty & $-0.296^{* *}$ & $0.149^{* *}$ & 0.025 & 0.027 & $-1.133^{* *}$ & $0.344^{* *}$ \\
in department & $(0.10)$ & $(0.06)$ & $(0.04)$ & $(0.07)$ & $(0.19)$ & $(0.16)$ \\
\hline Outside offer & $0.158^{*}$ & 0.092 & $0.115^{* *}$ & 0.017 & $-0.443^{* *}$ & $0.538^{* *}$ \\
& $(0.10)$ & $(0.08)$ & $(0.05)$ & $(0.07)$ & $(0.22)$ & $(0.19)$ \\
\hline Constant & $0.222^{*}$ & 0.100 & 0.055 & -0.005 & $0.519^{* *}$ & -0.064 \\
\hline Observations & $(0.12)$ & $(0.09)$ & $(0.06)$ & $(0.09)$ & $(0.26)$ & $(0.23)$ \\
\hline Test of $\alpha=0$ & 0.103 & $0.113^{*}$ & 0.064 & 0.004 & 0.261 & $0.273^{*}$ \\
\hline & $(0.09)$ & $(0.06)$ & $(0.04)$ & $(0.06)$ & $(0.174)$ & $(0.16)$ \\
\hline
\end{tabular}

aStandard errors in parentheses; * significant at 90\% level; ** significant at 95\% level.

${ }^{b}$ The first four models in table 3 are estimated only for counts greater than zero due to a large number of missing values.

${ }^{\mathrm{c}}$ The final two models are estimated with logit models, with a value of one indicating a respondent was asked to serve in the designated administrative role; zero otherwise.

${ }^{\mathrm{d} A}$ Poisson model is utilized because the negative binomial model fails to converge.

discipline, especially in terms of fewer reviewed articles and fewer editorial board positions.

\section{DISCUSSION}

This article addresses two important issues in academia: (1) whether women bargain less often than men for resources that help their careers, such as travel funds, research assistants, and special timing of the tenure clock; and (2) whether women provide more service to their universities and to their professions relative to men. We analyze 1,399 respondents in a 2009 APSA survey of political science faculty members. With respect to the question of "women don't' ask," our results suggest that women bargain more frequently than men for a wide variety of resources. The higher level of bargaining for female faculty is somewhat surprising given the broader set of findings in the literature that typically find the reverse pattern. ${ }^{15}$ One possible explanation of this empirical relationship is the selection effect for this particular sample. The APSA survey targets only those employed in faculty positions. It could be that women who are successful in gaining such posi-

However, our results also support the notion that women academics tend to provide service of a more "token" nature. We see that female respondents are significantly less likely than male respondents to report that they have been asked by their colleagues to serve as department chair or to direct a program.

In table 8, we look at gender differences in service to the academic profession. In the aggregate count of total service, we find no statistical differences between male and female respondents. However, women are more likely to serve on professional committees than men, which is consistent with the push for descriptive representation in professional settings. This finding is confirmed in table 4 as well when we consider the difference of means tests. Women are less likely to review books than men. Men report a significantly higher number of articles reviewed than women for the bivariate difference of means test in table 4. However, no differences in the number of articles reviewed or service on editorial boards appear in the multivariate count models. ${ }^{14}$ Rank has a positive and highly significant relationship with all types of disciplinary service. Working at a $P h D$-granting program and reporting an outside offer at one's current institution also increase the amount of service that faculty provide to their discipline. Yet the presence of tenured female faculty in a department reduces the total service faculty in the department provide to their tions have skills that make them more aggressive bargainers than their male counterparts. A second possible explanation is that women, especially those at more senior ranks, feel compelled to bargain for additional resources. This could occur if they perceive their male colleagues to be offered more salary or resources for a similar level of effort or if they are constrained in their mobility by their personal or family situation. ${ }^{16}$ Or conversely, perhaps junior women bargain more aggressively for resources than their senior women peers because they have more bargaining opportunities early in their academic careers. If women provide more service than their male faculty peers, they might also bargain more frequently to redress inequities in service loads. ${ }^{17}$

With respect to the second question of "women don't say no," we find solid evidence to support the claim that female faculty are asked to provide more service and that they engage in more service than male faculty. These differences are strongest at the local, university level, whereas women's disciplinary service is larger for only some categories of service (e.g., professional committees). Note that women also engage in less-prestigious service than men. Women are less likely to be asked to be department chair or to run a program than men. The service that women are engaging in is not necessarily helping to advance their careers. This result is troubling in light of the leaky pipeline in the academic profession 
Table 8

Service to Discipline ${ }^{a}$

\begin{tabular}{|c|c|c|c|c|c|}
\hline INDEPENDENT VARIABLES & $\begin{array}{l}\text { TOTAL } \\
\text { SERVICE }\end{array}$ & $\begin{array}{l}\text { \# OF BOOKS } \\
\text { REVIEWED }\end{array}$ & $\begin{array}{l}\text { \# OF ARTICLES } \\
\text { REVIEWED }\end{array}$ & $\begin{array}{c}\text { \# OF EDITORIAL } \\
\text { BOARDS }\end{array}$ & $\begin{array}{l}\text { \# OF PROFESSIONAL } \\
\text { COMMITTEES }\end{array}$ \\
\hline Rank & $\begin{array}{l}0.312^{* *} \\
(0.04)\end{array}$ & $\begin{array}{l}0.442^{* *} \\
(0.05)\end{array}$ & $\begin{array}{l}0.236^{* *} \\
(0.05)\end{array}$ & $\begin{array}{l}0.864^{* *} \\
(0.07)\end{array}$ & $\begin{array}{l}0.509^{* *} \\
(0.06)\end{array}$ \\
\hline Female & $\begin{array}{c}-0.080 \\
(0.06)\end{array}$ & $\begin{array}{l}-0.229 * * \\
(0.08)\end{array}$ & $\begin{array}{c}-0.068 \\
(0.09)\end{array}$ & $\begin{array}{l}0.155 \\
(0.11)\end{array}$ & $\begin{array}{l}0.422^{* *} \\
(0.10)\end{array}$ \\
\hline Minority & $\begin{array}{r}-0.135 \\
(0.08)\end{array}$ & $\begin{array}{l}-0.026 \\
(0.10)\end{array}$ & $\begin{array}{l}-0.222^{*} \\
(0.12)\end{array}$ & $\begin{array}{l}0.208 \\
(0.15)\end{array}$ & $\begin{array}{l}0.085 \\
(0.13)\end{array}$ \\
\hline Children & $\begin{array}{l}0.108^{*} \\
(0.06)\end{array}$ & $\begin{array}{l}0.006 \\
(0.08)\end{array}$ & $\begin{array}{l}0.146^{*} \\
(0.09)\end{array}$ & $\begin{array}{c}-0.032 \\
(0.12)\end{array}$ & $\begin{array}{c}0.123 \\
(0.10)\end{array}$ \\
\hline PhD program & $\begin{array}{l}0.794^{* *} \\
(0.07)\end{array}$ & $\begin{array}{l}0.060 \\
(0.08)\end{array}$ & $\begin{array}{l}1.076^{* *} \\
(0.09)\end{array}$ & $\begin{array}{l}0.945^{* *} \\
(0.11)\end{array}$ & $\begin{array}{l}0.566^{* *} \\
(0.11)\end{array}$ \\
\hline MA program & $\begin{array}{l}0.269 * * \\
(0.08)\end{array}$ & $\begin{array}{l}-0.067 \\
(0.10)\end{array}$ & $\begin{array}{l}0.362^{* *} \\
(0.11)\end{array}$ & $\begin{array}{l}0.239 \\
(0.15)\end{array}$ & $\begin{array}{l}0.530^{* *} \\
(0.13)\end{array}$ \\
\hline $\begin{array}{l}\text { Tenured female faculty } \\
\text { in department }\end{array}$ & $\begin{array}{l}-0.331^{* *} \\
(0.10)\end{array}$ & $\begin{array}{c}-0.185 \\
(0.12)\end{array}$ & $\begin{array}{l}-0.365^{* *} \\
(0.13)\end{array}$ & $\begin{array}{l}-0.651^{* *} \\
(0.22)\end{array}$ & $\begin{array}{c}-0.261 \\
(0.17)\end{array}$ \\
\hline Outside offer & $\begin{array}{l}0.220^{* *} \\
(0.07)\end{array}$ & $\begin{array}{l}0.187^{* *} \\
(0.08)\end{array}$ & $\begin{array}{r}0.138 \\
(0.09)\end{array}$ & $\begin{array}{l}0.619 * * \\
(0.10)\end{array}$ & $\begin{array}{l}0.477^{* *} \\
(0.10)\end{array}$ \\
\hline Constant & $\begin{array}{l}1.253^{* *} \\
(0.12)\end{array}$ & $\begin{array}{l}-0.341^{* *} \\
(0.16)\end{array}$ & $\begin{array}{l}0.911^{* *} \\
(0.17)\end{array}$ & $\begin{array}{l}-3.893^{* *} \\
(0.27)\end{array}$ & $\begin{array}{l}-2.209 * * \\
(0.22)\end{array}$ \\
\hline Observations & 1,035 & 1,071 & 1,071 & 1,071 & 1,071 \\
\hline Test of $\alpha=0$ & $\chi^{2}=8137^{* *}$ & $\chi^{2}=1438^{* *}$ & $x^{2}=9086^{* *}$ & $\chi^{2}=241^{* *}$ & $\chi^{2}=507^{* *}$ \\
\hline
\end{tabular}

extract a negative toll on female scholars' careers in fewer hours devoted to research and fewer published articles. We should also consider policies that could reward women for additional service, such as course-load reductions, to help offset the time spent on service. Given that women are bargaining more frequently than men, they might also use those bargaining opportunities to negotiate better service loads as well.

\section{ACKNOWLEDGMENTS}

An earlier version of this paper was presented at the 2011 International Studies Association conference in Montreal, Canada, and the University of Iowa's Social Science Interdisciplinary Group Colloquium. We are grateful to Jae Mook Lee for research assistance and to Lyn Boyd-Judson, Jennifer Glass, Kathleen Hancock, Karen Heimer, Tracy Osborn, Beth Simmons, and Laura Sjoberg for their useful comments. because the results show that women are doing more service at higher ranks, but that work is not translating into the type of prestigious service that may advance their salary or career more generally. There are no gender differences with respect to editorial board service, despite the perception that many editors try to ensure diversity on their boards (Stegmaier, Palmer, and van Assendelft 2011).

Future analyses should consider the outcomes of women's bargaining situations more carefully, such as job and salary satisfaction. Much of the bargaining literature suggests that women are less successful when they initiate negotiations and that they are perceived more negatively by their peers when they bargain. We have begun some preliminary analyses in the APSA survey to look at the effect of bargaining on these types of outcomes. Our initial results suggest that women who bargain more are not more satisfied with their salary relative to men and that women respondents are more likely to report genderbased salary discrimination. We also find that bargaining for more resources does not result in a significant improvement in a respondent's perceived influence on important decisions facing their department, such as tenure or hiring decisions. We will explore these outcomes of bargaining more fully in future research.

In terms of the leaky pipeline in academia, department chairs and deans need to consider the additional service burden that female faculty may face. We should consider ways to protect the time of female faculty, especially in the years of the associate rank when women often are asked to do more service. Other studies have shown that this extra effort to service, teaching, and advising all

\section{NOTES}

1. Some of the most prestigious academic service positions include serving as department chair or a higher level administrator (e.g. dean, provost), editing a major journal, serving on editorial boards of highly reputable journals, chairing important committees at the university or professional level, or serving as director of an institution within one's university.

2. However, bargaining for more resources does not necessarily translate into higher job satisfaction or efficacy for women, especially if those bargaining attempts are unsuccessful (Babcock and Laschever 2003).

3. As seen in appendix A, the APSA survey has a higher percentage of female respondents at the full professor level in comparison to the association at large, which is closer to $20-21 \%$ women for all APSA faculty.

4. See http://www.aaup.org/AAUP/comm/rep/Z/ecstatreport10-11/.

5. Analyzing the 1987 NSOPF survey, Singell, Lillydahl, and Singell (1996) also found significant differences in time allocation across different types of institutions (premier, doctoral, comprehensive, or liberal arts colleges/ universities), which has a gender dimension given that women are more highly represented at comprehensive and liberal arts colleges.

6. According to data compiled by the National Science Foundation in $2009,40 \%$ of political science $\mathrm{PhD}$ recipients are women, compared with the national average of $46.8 \%$ women. The representation of women in academic fields ranges from $13 \%$ to $95 \%$ of $\mathrm{PhDs}$. 〈http://www.nsf.gov/statistics/nsf11306/ appendix/excel/tab15.xls .

7. The number in parentheses reports the mean for each count variable.

8. The APSA survey combines information about position and tenure to create this scale. There are a few individuals who are assistant professors with tenure $(\mathrm{N}=15)$ and a few individuals who are associate or full professors without tenure $(\mathrm{N}=21)$, but these represent a small total of the overall number of respondents. Ninety seven percent of associate and full professors have tenure while $96 \%$ of assistant professors do not have tenure. The overall number of respondents who fall into the lecturer/instructor/fellow category is small $(\mathrm{N}=$ 31 ), and there is a mixture of tenured/nontenured positions at this level.

9. We find a similar result when counting the number of children at home. Respondents with a higher number of children at home are more likely to bargain for resources. 
10. This also allows for us to drop the instructor/postdoc/lecturer group from our sample, who may have different opportunities for service and bargaining than tenure-track faculty. These results are available from the authors on request.

11. For a summary of parental leave policies for the top 50 ranked political science departments in the United States, see http://www.saramitchell.org.

12. These results are available from the authors on request.

13. Analyses using a measure for number of children at home show a positive relationship with all forms of service, both to the university and the discipline.

14. However, serving on editorial boards and reviewing articles and books are certainly correlated with research productivity, which has been shown to be lower for women using this APSA survey data (Hesli and Lee 2011). The bivariate correlation between number of published articles and number of editorial boards served on is 0.50 while the bivariate correlation between number of articles reviewed and number of articles published is 0.49 .

15. Yet this finding does not tell us whether women have higher or lower success rates than men when bargaining. As noted previously, the survey question reports cases where respondents received the various resources (e.g., research assistants) by asking for them, receiving them as part of an external award, or having them offered by the university. If a gendered difference in bargaining upfront exists, this could bias the sample for which we have data on these indicators to a group of women who are particularly successful in bargaining.

16. The 1999 MIT study on the status of female faculty in the sciences (http:// web.mit.edu/fnl/women/women.html), for example, found that female junior faculty perceived no differences in the treatment of male and female faculty, whereas senior women perceived that men had higher salaries, larger labs, and more resources in general.

17. It is possible that there are differences between the business and academic job sectors that creates different patterns of gendered bargaining. Academia offers a wide range of nonsalary items that are negotiable.

\section{REF E R E N C E S}

Allen, Henry L. 1998. "Faculty Workload and Productivity: Gender Comparisons." In The NEA Almanac of Higher Education. Washington, DC: National Education Association.

Babcock, Linda, Michele Gelfand, Deborah Small, and Heidi Stayn. 2006. "Gender Differences in the Propensity to Initiate Negotiations." In Social Psychology and Economics, eds. D.D. Cremem, M. Zeelendberg, and J.K. Murnighan, 239-59. Mahwah, NJ: Lawrence Erlbaum.

Babcock, Linda, and Sara Laschever. 2003. Women Don't Ask: Negotiation and the Gender Divide. Princeton, NJ: Princeton University Press.

Bell, Linda A. 2001. "Uncertain Times: The Annual Report on the Economic Status of the Profession 2000-2001." Academe 87 (2): 25-98.

Bellas, Marcia L., and Robert K. Toutkoushian. 1999. "Faculty Time Allocations and Research Productivity: Gender, Race and Family Effects." The Review of Higher Education 22 (4): 367-90.

Blackaby, David, Allison L. Booth, and Jeff Frank. 2005. "Outside Offers and the Gender Pay Gap: Empirical Evidence from the UK Academic Labour Market." The Economic Journal 115 (501): F81-F107.

Bowles, Hannah Riley, Linda Babcock, and Lei Lai. 2006. "Social Incentives for Gender Differences in the Propensity to Initiate Negotiations: Sometimes It Does Hurt to Ask." Organizational Behavior and Human Decision Processes 103 (1): 84-103.

Breuning, Marijke, Joseph Bredehoft, and Eugene Walton. 2005. "Promise and Performance: An Evaluation of Journals in International Relations." International Studies Perspective 6 (4): 447-61.

Breuning, Marijke, and Kathryn Sanders. 2007. "Gender and Journal Authorship in Eight Prestigious Political Science Journals." PS: Political Science and Politics $40(2): 347-51$.

Chesterman, Coleen, Anne Ross-Smith, and Margaret Peters. 2005. "Not Doable Jobs! Exploring Senior Women's Attitudes to Academic Leadership Roles." Women's Studies International Forum 28 (2-3): 163-80.

Gerhart, Barry. 1990. "Gender Differences in Current and Starting Salaries: The Role of Performance, College Major, and Job Title." Industrial and Labor Relations Review 43 (4): 418-33.

Gerhart, Barry, and Sara Rynes. 1991. "Determinants and Consequences of Salary Negotiations by Male and Female MBA Graduates." Journal of Applied Psychology 76 (2): 256-62

Greig, Fiona. 2008. "Propensity to Negotiate and Career Advancement: Evidence from an Investment Bank that Women are on a 'Slow' Elevator." Negotiation Journal 24 (4): 495-508.
Henehan, Marie T., and Meredith Reid Sarkees. 2009. "Open Doors and Closed Ceilings: Gender-Based Patterns and Attitudes in the International Studies Association." International Studies Perspectives 10 (4): 428-46.

Hesli, Vicki, and Barbara Burrell. 1995. "Faculty Rank Among Political Scientists and Reports on the Academic Environment: The Differential Impact of Gender on Observed Patterns." PS: Political Science and Politics 28 (1): 101-11

Hesli, Vicki L., Jacqueline DeLaat, Jeremy Youde, Jeanette Mendez, and Sang-shin Lee. 2006. "Success in Graduate School and After: Survey Results from the Midwest Region Part III." PS: Political Science and Politics 39 (2): 317-25.

Hesli, Vicki L., Evelyn C. Fink, and Diane M. Duffy. 2003. "Mentoring in a Positive Graduate Student Experience: Survey Results from the Midwest Region, Part I." PS: Political Science and Politics 36 (3): 457-6o.

Hesli, Vicki L., and Jae Mook Lee. 2011. "Faculty Research Productivity: Why Do Some of Our Colleagues Publish More than Others?" PS: Political Science and Politics 44 (2): 393-408.

Jacobs, Jerry A. 2004. "The Faculty Time Divide." Sociological Forum 19 (1): 3-27.

Jaschik, Scott. 2005. "Gender Gap in Publishing." Inside HigherEd (September 6).

Link, Albert N., Christopher A. Swann, and Barry Bozeman. 2008. "A Time Allocation Study of University Faculty." Economics of Education Review 27 (4): 363-74.

Mathews, A. Lanethea, and Kristi Andersen. 2001. "A Gender Gap in Publishing? Women's Representation in Edited Political Science Books." PS: Political Science and Politics 34 (1): 143-47.

Milem, Jeffrey F., Joseph B. Berger, and Eric L. Dey. 20oo. "Faculty Time Allocation: A Study of Change over Twenty Years." The Journal of Higher Education 71 (4): 454-75

Misra, Joya, Jennifer Hickes Lundquist, Elissa Holmes, and Stephanie Agiomavritis. 2011. "The Ivory Ceiling of Service Work." Academe Online. 〈http://www. aaup.org/AAUP/pubsres/academe/2011/JF/Feat/misr.htm $\rangle$.

Monroe, Kristen, Saba Ozyurt, Ted Wrigley, and Amy Alexander. 2008. "Gender Equality in Academia: Bad News from the Trenches, and Some Possible Solutions." Perspectives on Politics 6 (2): 215-33.

Park, Shelley M. 1996. "Research, Teaching, and Service: Why Shouldn't Women's Work Count?" The Journal of Higher Education 67 (1): 46-84.

Perna, Laura W. 2001. "Sex and Race Differences in Faculty Tenure and Promotion." Research in Higher Education 42 (5): 541-67.

Porter, Stephen R. 2007. "A Closer Look at Faculty Service: What Affects Participation on Committees? The Journal of Higher Education 78 (5): 523-41.

Rudman, Laurie A. 1998. "Self-Promotion as a Risk Factor for Women: The Costs and Benefits of Counterstereotypical Impression Management." Journal of Personality and Social Psychology 74 (3): 629-45.

Russell, Susan H., James S. Fairweather, and Robert M. Hendrickson. 1991. Profiles of Faculty in Higher Education Institutions, 1988. Washington, DC: US Department of Education Office of Educational Research and Improvement. (NCES 91-389).

Sarkees, Meredith Reid, and Nancy E. McGlen. 1999. "Misdirected Backlash: The Evolving Nature of Academia and the Status of Women in Political Science." PS: Political Science and Politics 32 (1): 100-07.

Singell, Larry D., Jr., Jane H. Lillydahl, and Larry D. Singell, Sr. 1996. "Will Chang ing Times Change the Allocation of Faculty Time?" Journal of Human Resources 31 (2): 429-49.

Stegmaier, Mary, Barbara Palmer, and Laura van Assendelft. 2011. "Getting on the Board: The Presence of Women in Political Science Journal Editorial Positions." PS: Political Science and Politics 44 (4): 799-804.

Toutkoushian, Robert K. 1999. "The Status of Academic Women in the 199os: No Longer Outsiders, but Not Yet Equals." Quarterly Review of Economics and Finance 39 (5): 679-98.

Turk, Theresa Guminski. 1981. "Women Faculty in Higher Education: Academic Administration and Governance in a State University System, 1966-1977." Pacific Sociological Review 24 (2): 212-36.

Turner, Caroline Sotello Viernes. 2002. "Women of Color in Academe: Living with Multiple Marginality." Journal of Higher Education 73 (1): 74-93.

Turner, Caroline Sotello Viernes, and Samuel L. Myers 2002. Faculty of Color in Academe: Bittersweet Success. Boston: Allyn and Bacon.

Twale, Darla J., and David M. Shannon. 1996. "Professional Service Involvement of Leadership Faculty: An Assessment of Gender, Role, and Satisfaction." Sex Roles 34 (1/2): 117-26.

Winslow, Sarah. 2010. "Gender Inequality and Time Allocations among Academic Faculty." Gender and Society 24 (6): 769-93. 


\section{APPENDIX A: Descriptive Statistics}

\begin{tabular}{|c|c|c|c|c|c|}
\hline INDEPENDENT VARIABLES & $N$ & MEAN & $\begin{array}{l}\text { STANDARD } \\
\text { DEVIATION }\end{array}$ & MINIMUM & MAXIMUM \\
\hline Rank & 1305 & 3.05 & 0.89 & 1 & 4 \\
\hline Female & 1399 & 0.25 & 0.43 & 0 & 1 \\
\hline Minority & 1399 & 0.11 & 0.31 & 0 & 1 \\
\hline Children & 1399 & 0.53 & 0.50 & 0 & 1 \\
\hline PhD program & 1399 & 0.32 & 0.47 & 0 & 1 \\
\hline MA program & 1399 & 0.19 & 0.39 & 0 & 1 \\
\hline Tenured female faculty & 1399 & 0.09 & 0.29 & 0 & 1 \\
\hline Outside offer & 1399 & 0.27 & 0.44 & 0 & 1 \\
\hline DEPENDENT VARIABLES & $N$ & MEAN & $\begin{array}{l}\text { STANDARD } \\
\text { DEVIATION }\end{array}$ & MINIMUM & MAXIMUM \\
\hline Projects Supervised & 1170 & 3.73 & 6.46 & 0 & 111 \\
\hline Total Advisees & 1210 & 24.02 & 40.50 & 0 & 500 \\
\hline \multicolumn{6}{|l|}{ Service (Internal) } \\
\hline Volunteered & 1399 & 0.52 & 1.16 & 0 & 10 \\
\hline Asked to Serve & 1399 & 1.23 & 1.93 & 0 & 11 \\
\hline Served & 1399 & 2.69 & 2.45 & 0 & 13 \\
\hline Chaired & 1399 & 1.03 & 1.50 & 0 & 11 \\
\hline Department Chair & 1191 & 0.41 & 0.49 & 0 & 1 \\
\hline Program Director & 1134 & 0.41 & 0.49 & 0 & 1 \\
\hline \multicolumn{6}{|l|}{ Service (External) } \\
\hline Total & 1178 & 15.46 & 17.4 & 0 & 137 \\
\hline Books reviewed & 1399 & 2.52 & 3.86 & 0 & 50 \\
\hline Articles reviewed & 1399 & 8.74 & 13.82 & 0 & 80 \\
\hline Editorial boards & 1399 & 0.71 & 1.61 & 0 & 22 \\
\hline Prof. committees & 1399 & 1.05 & 1.92 & 0 & 25 \\
\hline \multicolumn{6}{|l|}{ Total Resources } \\
\hline Asked for & 1399 & 1.46 & 1.83 & 0 & 8 \\
\hline Part external award & 1399 & 0.53 & 1.22 & 0 & 8 \\
\hline Offer by university & 1399 & 2.27 & 2.15 & 0 & 10 \\
\hline Outside offer & 1399 & 0.27 & 0.44 & 0 & 1 \\
\hline
\end{tabular}

\section{APPENDIX B: Survey Methodology}

\section{QUESTIONNAIRE DESIGN}

In 2005, the APSA Committee on the Status of Women in the Profession (CSWP) proposed to the president of APSA that the association conduct research associated with the recommendations that emerged from the March 2004 Workshop on Women's Advancement in Political Science organized by Michael Brintnall and Linda Lopez (APSA), Susan Clarke (University of Colorado, Boulder), and Leonie Huddy (Stony Brook University). Once the research proposal was approved, the CSWP used questionnaires that had been employed in research published by Hesli and Burrell (1995); Hesli, Fink, and Duffy (2003); and Hesli et al. (2006) to develop a new survey instrument. Additional questions were added from questionnaires developed by the National Research Council and the University of Michigan's Fall 2001 Survey of Academic Climate and Activities, which was created for an NSF ADVANCE project. The following reports were also used to help generate questions:

- Blau, F. 2002. "Report of the Committee on the Status of Women in the Economics Profession." American Economic Review 92: 516-20.

- Commission on Professionals in Science and Technology (CPST). 2000. Professional Women and Minorities: A Total Human Resource Data Compendium. 13th ed. Washington, DC: CPST. 


\section{APPENDIX B: (Continued)}

- Creamer, Elizabeth. 1998. Assessing Faculty Publication Productivity: Issues of Equity. ASHE-ERIC Higher Education Report, Vol. 26, No. 2. Washington, DC: George Washington University.

- Fox, Mary Frank. 1995. “Women and Scientific Careers." In Handbook of Science and Technology Studies, ed. S. Jasanoff, J. Markle, J. Petersen, and T. Pinch, 205-23. Newbury Park, CA: Sage.

- Fox, Mary Frank. 1998. "Women in Science and Engineering: Theory, Practice, and Policy in Programs." Signs: Journal of Women in Culture and Society 24: 201-23.

- Sarkees, Meredith Reid, and Nancy E. McGlen. 1992. "Confronting Barriers: The Status of Women in Political Science." Women and Politics 12 (4): 43-86.

A draft copy of the questionnaire was circulated to the members of the APSA status committees. The questionnaire was revised and expanded to address the concerns of the members of the status committees. The instrument was pilot-tested by distributing it to all political science faculty members at one research university and one private four-year college. The feedback from the pilot test was used to make further revisions to the questionnaire.

\section{SAMPLE SELECTION}

We used as our target population the names contained within the APSA "faculty" file. We used this file of 11,559 names to create a sample population file of size 5,179 names. The original "faculty" file was stratified by department size. To ensure the adequate representation of faculty members from medium- and small-size schools, we oversampled from these groups. Names were selected randomly from the "faculty" file for the "sample" file.

\section{SURVEY PROCEDURE}

Using e-mail addresses, all persons in the sample file were sent a letter of invitation to participate in the study from the executive director and the president of the APSA. Bad e-mail addresses (addresses that bounced back) were replaced with random selections from the "faculty" file. These persons were also mailed an invitation letter. The cleaned "survey" file was sent to the Survey Research Center at the Pennsylvania State University (SRC).

Individuals in the sample were sent an e-mail from SRC inviting them to participate in the survey. This invitation included a link to the web-based survey containing a unique identifier for each potential participant. Only one completed survey was allowed for each identifier. The initial invitation was e-mailed to respondents on August 27, 2009. Follow-up reminders were sent to non-responders on September 10, 2009; September 24, 2009: October 8, 2009; and October 29, 2009. From among the 5,179 original addresses, 1,399 completed the survey (252 invalid addresses, 105 refusals, and 3,423 non-respondents).

According to APSA data, the percentage of females in the population from which we drew the sample (all political science faculty members in the United States) was $28 \%$ in 2009 . Breaking this down by rank and institution type, we get the following distributions:

\begin{tabular}{llcc}
$\begin{array}{l}\text { HIGHEST DEGREE GRANTED IN } \\
\text { THE HOME DEPARTMENT }\end{array}$ & ACADEMIC RANK & $\begin{array}{c}\text { PERCENT FEMALE AMONG } \\
\text { SURVEY RESPONDENTS }\end{array}$ & $\begin{array}{c}\text { PERCENT FEMALE IN PROFESSION } \\
\text { (APSA DATA FOR 2009) }\end{array}$ \\
\hline Ph.D.-Granting Department & Assistant & 50 & 39 \\
& Associate & 22 & 32 \\
& Full & 29 & 20 \\
\hline MA-Granting Department & Assistant & 48 & 40 \\
& Associate & 25 & 32 \\
& Full & 24 & 21 \\
\hline BA-Granting Four-Year College & Assistant & 39 & 42 \\
& Associate & 36 & 31 \\
& Full & 16 & 17 \\
\hline
\end{tabular}




\section{APPENDIX C: Variables Included}

\section{DEPENDENT VARIABLES}

Projects Supervised

Survey Question: On average, how many of the following undergraduate projects do you supervise each semester (or per quarter)?

Number of honors thesis

Number of independent studies

Number of senior projects

Counts are summed for the three items with missing values coded as zero.

Total Advisees

Survey Question: For how many of each of the following types of individuals do you currently serve as official advisor?

$$
\begin{aligned}
& \text { undergraduates } \\
& \text { MA students } \\
& \text { PhD students } \\
& \text { post-docs }
\end{aligned}
$$

Counts are summed for the five items with missing values coded as zero.

\section{Service (Internal)}

Survey Question: We're interested in knowing your level of involvement in committee work at your institution. For each of the following, please specify your level of participation by checking the appropriate boxes. (Check all that apply for each committee for all the years of your current employment.)

\section{NO PARTICIPATION VOLUNTEERED ASKED TO SERVE SERVED CHAIRED}

Departmental level committees
Curriculum
Department executive
Faculty search
Fellowship
Graduate admission
Other (please least)
School/college level committees
College curriculum
College executive
Faculty search
Other (please list)
University level committees
Faculty governance
Administrative
Admissions
Budgetary

Measures for Volunteered, Asked to Serve, Served, and Chaired are created by summing across all committee levels, with missing values treated as zero.

Survey Question: Have you ever been asked to serve and/or served as any of the following?

\section{NO YES, SERVED ASKED, BUT DID NOT SERVE}

\begin{tabular}{l} 
a. Department chair \\
\hline b. Department program or section director \\
c. Center/lab/institute/program director or administrator
\end{tabular}

Variable for Department Chair is taken from (a) with "No" coded as 0 and "Yes, served" and "Asked, but did not serve" coded as 1. Variable for Program Director is taken from (b) with "No" coded as 0 and "Yes, served" and "Asked, but did not serve" coded as 1. 


\section{APPENDIX C: (Continued)}

Service (External)

Survey Question: In terms of service for your profession, please indicate the number of times (in the past five years) you have done any of the following: (Indicate how many next to each category)

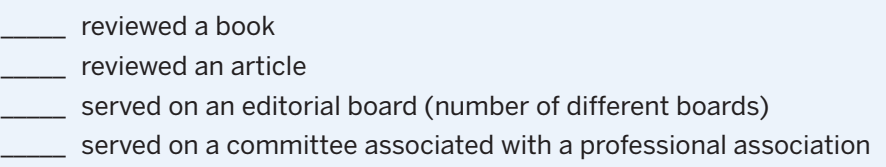

Variable for Total sums across all items with missing values set to zero.

Variables for Books reviewed, Articles reviewed, Editorial boards, and Professional committees utilize the counts for the specific category of service, with missing values set to zero.

\section{Total Resources}

Survey Question: Have you received any of the following resources as a result of your own negotiations, the terms of an award, or as part of an offer by the university, since your initial contract at your current position? If so, please check all that apply.

\begin{tabular}{l} 
ASKED/BARGAINED FOR BY ME PART OF AN EXTERNAL AWARD OFFERED BY UNIVERSITY \\
\hline Course release time \\
\hline Research assistant \\
\hline Discretionary funds \\
\hline Travel funds \\
\hline Summer salary \\
\hline Special timing of tenure track \\
\hline Moving expenses \\
\hline Housing subsidy \\
\hline Child care \\
\hline Partner/spouse position \\
Clerical support \\
Other ( please specify)
\end{tabular}

Measures for Asked for, Part external award, and Offer by university are created by summing down each column, with missing values treated as zero.

The percentages in Table 3 are taken from the individual items respondents bargained for.

\section{INDEPENDENT VARIABLES}

Rank

Survey Question: What is the title of your primary current appointment?

We created an ordinal variable using the following coding: 1 (instructors, lecturers, postdocs and fellows), 2 (assistant professors), 3 (associate professors), and 4 (full professors, emeritus, and administrative positions).

Female

Survey Question: What is your gender?
a. Male
b. Female
c. Transgender

The dummy variable equals 1 if the response is $b$.

Minority

Survey Question: Do you identify yourself as a member of an ethnic and racial minority group?

- a. Yes

- b. No

_c. Don't know

The dummy variable equals 1 if the response is a. 


\section{APPENDIX C: (Continued)}

\section{Children}

Survey Question: Do you or a spouse/partner of yours have any children?
a. Yes
b. No

The dummy variable equals 1 if the response is a.

\section{PhD Program, MA Program}

Survey Question: Type of department where you are employed:

a. Ph.D. granting program

b. M.A. granting program

c. Department within a 4 year college

d. Department within a 2 year college

e. Other academic unit (specify)

The dummy variable for $\mathrm{PhD}$ program equals 1 if the response is a.

The dummy variable for MA program equals 1 if the response is $b$.

Tenured Female Faculty

Survey Question: Among the female faculty members in your department, are any tenured?
a. Yes
b. No

The dummy variable equals 1 if the response is a.

\section{Outside Offer}

Survey Question: Have you ever had an outside offer while at your current position?
a. Yes
b. No

The dummy variable equals 1 if the response is a. 